\title{
MCR under Microwave Irradiation: Synthesis in Water of New 2-Amino-bis(2-phosphonoacetic) Acids
}

\author{
Didier Villemin*D, Bernard Moreau and Nathalie Bar \\ Normandie Université, France, ENSICAEN, LCMT, UMR CNRS 6507, INC3M, FR 3038, Labex EMC3, \\ Labex SynOrg, 14050 Caen, France; bernard.moreau@ensicaen.fr (B.M.); nathalie.bar@ensicaen.fr (N.B.) \\ * Correspondence: didier.villemin@ensicaen.fr; Tel.: +33-231-452-840
}

\begin{abstract}
Novel 2-amino bis(2-phosphonoacetic) acids were prepared by microwave irradiation of a mixture of amine, glyoxylic acid and phosphorous acid. The reaction takes place with various amines including primary and secondary amines and polyamines, but this reaction is more sensitive to steric hindrance of amine than the similar Kabachnik-Fields reaction. Amino acids can be also transformed into the expected bis(2-phosphonoacetic) acids, with the exception of tryptophan, which gives a $\beta$-carboline product.
\end{abstract}

Keywords: multicomponent reaction (MCR); aminophosphonic acetic acid; green conditions; microwave irradiation

check for

updates

Citation: Villemin, D.; Moreau, B.; Bar, N. MCR under Microwave Irradiation: Synthesis in Water of New 2-Amino-bis(2phosphonoacetic) Acids. Organics 2021, 2, 98-106. https://doi.org/ 10.3390 /org2020009

Academic Editor: Tomasz

K. Olszewski

Received: 23 March 2021

Accepted: 28 April 2021

Published: 11 May 2021

Publisher's Note: MDPI stays neutral with regard to jurisdictional claims in published maps and institutional affiliations.

Copyright: (c) 2021 by the authors. Licensee MDPI, Basel, Switzerland. This article is an open access article distributed under the terms and conditions of the Creative Commons Attribution (CC BY) license (https:// creativecommons.org/licenses/by/ $4.0 /)$.

\section{Introduction}

Aminophosphonic acids are structurally analogous to aminocarboxylic acids, and their derivatives have received considerable attention [1-3]. These compounds exhibit a large variety of biological activities such as peptide mimics [4], enzyme inhibitors [5,6] (inhibitors of GABA receptors, inhibitors of various proteolytic enzymes, inhibitors of dialkylglycine decarboxylase), antibiotics, crop protection agents [7] or even haptens [8] of catalytic antibodies. $\alpha$-Aminophosphonic acids have found applications, including in the materials fields as complexones $[9,10]$, as anti-corrosive agents [11,12], for extraction of metals [13] and surface modifications [14]. $\alpha$-Aminophosphonic acids are also used as precursors in the synthesis of 2D or 3D hybrid materials involving different metals (M(IV) or M(II)) [15]. Some of these hybrid phosphonates may have practical applications as supported catalysts [16], protonic conductors [17] and molecular sieves. The multicomponent reaction (MCR) of formaldehyde, phosphorous acid and an amine leading to an aminophosphonic acid was first described by Moedritzer and Irani [18] according to the Scheme 1. It is performed in an aqueous medium and can be activated by microwave irradiation [19-21].

$$
\mathrm{R}-\mathrm{NH}_{2}+\mathrm{HCHO}+\mathrm{H}_{3} \mathrm{PO}_{3} \longrightarrow \mathrm{R}-\mathrm{NHCH}_{2}-\mathrm{PO}(\mathrm{OH})_{2}
$$

Scheme 1. Moedritzer-Irani reaction: synthesis of aminophosphonic acids by reaction of amine, formaldehyde and phosphorous acid.

This reaction cannot be generalized with other aldehydes, unlike the reaction of Kabachnik-Fields [22-24], in which a dialkylphosphonate is used instead of phosphorous acid according to the Scheme 2. The Moedritzer-Irani reaction has, however, the advantage of leading directly to the free acids by not needing a tedious deprotection of phosphonates by Bronsted [25] or Lewis acid [26]. 


$$
\mathrm{R}-\mathrm{NH}_{2}+\mathrm{R}^{\prime}-\mathrm{CHO}+\mathrm{HPO}\left(\mathrm{OR}^{\prime \prime}\right)_{2} \longrightarrow \mathrm{R}-\mathrm{NH}-\mathrm{CH}\left(\mathrm{R}^{\prime}\right)-\mathrm{PO}(\mathrm{OR} ")_{2}
$$

Scheme 2. Kabachnik-Fields reaction: synthesis of aminophosphonates by reaction of amine, aldehyde and dialkylphosphonate.

\section{Materials and Methods}

All chemicals used were purchased from Aldrich or Fluka. The infrared spectra were recorded on a Perkin Elmer One ATR spectrophotometer. Samples were analyzed by NMR spectrometry; analyses were carried out with Fourier Bruker B 400 spectrometer. Samples of the isolated products were diluted in $\mathrm{D}_{2} \mathrm{O}$ in the presence of $\mathrm{Na}_{2} \mathrm{CO}_{3}$. Microwave irradiation reactions were performed in a microwave oven, Synthewave 402 (Prolabo), working at a frequency of $2450 \mathrm{MHz}$ and with a control of the power of themicrowave irradiation.

\subsection{General Procedure for Amines}

One equivalent of amine and two equivalents phosphorous acid are mixed with a little amount of water and placed in a quartz tube. Then, two equivalents of glyoxylic acid monohydrate are quickly added, and the flask is irradiated at $240 \mathrm{~W}$ for $15 \mathrm{~min}$. After cooling, when the product precipitates in the tube, it is then filtered and washed with water.

\subsection{Octylamino-2-iphosphonic Acetic Acid}

$2.58 \mathrm{~g}$ of octylamine ( $20 \mathrm{mmol}), 3.28 \mathrm{~g}$ of phosphorous acid $(40 \mathrm{mmol}), 4 \mathrm{~mL}$ of water and $3.68 \mathrm{~g}$ glyoxylic acid monohydrate $(40 \mathrm{mmol})$ were used according to the amines' general procedure. White solid, isolated yield $39 \% . \mathrm{Mp}=216-217{ }^{\circ} \mathrm{C} .{ }^{1} \mathrm{H}-\mathrm{NMR}\left(\mathrm{D}_{2} \mathrm{O}\right)$ : $0.80\left(\mathrm{t}, \mathrm{J}=6.4 \mathrm{~Hz}, 3 \mathrm{H}, \mathrm{CH}_{3}\right) ; 1.22-1.26\left(\mathrm{~m}, 10 \mathrm{H}, \mathrm{CH}_{2}\right) ; 1.57\left(\mathrm{t}, \mathrm{J}=7.2 \mathrm{~Hz}, 2 \mathrm{H}, \mathrm{CH}_{2}\right)$; $2.78\left(\mathrm{t}, \mathrm{J}=7.2 \mathrm{~Hz}, 2 \mathrm{H}, \mathrm{CH}_{2}-\mathrm{N}\right) ; 3.37\left(\mathrm{~s}, 2 \mathrm{H}, 2^{*} \mathrm{~N}-\mathrm{CH}-\mathrm{P}\right) .{ }^{13} \mathrm{C}-\mathrm{NMR}\left(\mathrm{D}_{2} \mathrm{O}\right): 13.8\left(\mathrm{CH}_{3}\right) ; 22.6$; 27.0; 27.5; 29.34; $29.37\left(5 \mathrm{CH}_{2}\right) ; 31.9\left(\mathrm{CH}_{2}-\mathrm{N}\right) ; 48.2 ; 50.8(\mathrm{~N}-\mathrm{CH}-\mathrm{P}) ; 165.6 ; 174.5(\mathrm{C}=\mathrm{O})$. ${ }^{31} \mathrm{P}-\mathrm{NMR}\left(\mathrm{D}_{2} \mathrm{O}\right): 4.9 \mathrm{ppm}$.

\subsection{Decylamino-2-diphosphonic Acetic Acid}

$2.36 \mathrm{~g}$ of decylamine $(15 \mathrm{mmol}), 2.47 \mathrm{~g}(30 \mathrm{mmol})$ phosphorus acid, $10 \mathrm{~mL}$ of water and $2.78 \mathrm{~g}$ glyoxylic acid monohydrate $(30 \mathrm{mmol})$ were used according to the amines' general procedure. White solid, isolated yield $40 \% . \mathrm{Mp}=227-228{ }^{\circ} \mathrm{C} .{ }^{1} \mathrm{H}-\mathrm{NMR}\left(\mathrm{D}_{2} \mathrm{O}\right): 0.80$ $\left(\mathrm{t}, \mathrm{J}=6.8 \mathrm{~Hz}, 3 \mathrm{H}, \mathrm{CH}_{3}\right) ; 1.20-1.30\left(\mathrm{~m}, 16 \mathrm{H}, \mathrm{CH}_{2}\right) ; 3.26\left(\mathrm{t}, \mathrm{J}=6.8 \mathrm{~Hz}, 2 \mathrm{H}, \mathrm{CH}_{2}-\mathrm{N}\right) ; 3.90(\mathrm{~s}$, $2 \mathrm{H}, \mathrm{N}-\mathrm{CH}-\mathrm{P}) .{ }^{13} \mathrm{C}-\mathrm{NMR}\left(\mathrm{D}_{2} \mathrm{O}\right): 14.1\left(\mathrm{CH}_{3}\right) ; 22.7 ; 26.5 ; 28.2 ; 29.1 ; 29.3,29.5\left(8 * \mathrm{CH}_{2}\right) ; 31.9$ $\left(\mathrm{CH}_{2}-\mathrm{N}\right) ; 44.1 ; 48.8(\mathrm{~N}-\mathrm{CH}-\mathrm{P}) ; 164.0 ; 171.9(\mathrm{C}=\mathrm{O}) .{ }^{31} \mathrm{P}-\mathrm{NMR}\left(\mathrm{D}_{2} \mathrm{O}\right): 4.2 \mathrm{ppm}$.

\subsection{Dodecylamino-2-diphosphonic Acetic Acid}

$3.70 \mathrm{~g}$ of dodecylamine ( $20 \mathrm{mmol}), 3.28 \mathrm{~g}$ of phosphorous acid $(40 \mathrm{mmol}), 4 \mathrm{~mL}$ of water and $3.68 \mathrm{~g}$ of glyoxylic acid monohydrate $(40 \mathrm{mmol})$ were used according to the amines' general procedure. White solid, isolated yield $50 \% . \mathrm{Mp}=238-239^{\circ} \mathrm{C} .{ }^{1} \mathrm{H}-\mathrm{NMR}$ (DMSO): $0.86\left(\mathrm{t}, \mathrm{J}=6.8 \mathrm{~Hz}, 3 \mathrm{H}, \mathrm{CH}_{3}\right) ; 1.25-1.35\left(\mathrm{~m}, 18 \mathrm{H}, \mathrm{CH}_{2}\right) ; 1.62\left(\mathrm{~m}, 2 \mathrm{H}, \mathrm{CH}_{2}\right) ; 2.87(\mathrm{t}, \mathrm{J}=8.0 \mathrm{~Hz}$, $2 \mathrm{H}, \mathrm{CH}_{2}-\mathrm{N}$ ); 3.80 (s, 2H, N-CH-P). ${ }^{13} \mathrm{C}-\mathrm{NMR}$ (DMSO): $13.9\left(\mathrm{CH}_{3}\right) ; 22.1 ; 25.1 ; 25.8 ; 25.9$; $28.5 ; 28.7 ; 28.8 ; 28.9 ; 28.95 ; 29.0\left(10 * \mathrm{CH}_{2}\right) ; 31.3\left(\mathrm{CH}_{2}-\mathrm{N}\right) ; 46.6 ; 46.8(\mathrm{~N}-\mathrm{CH}-\mathrm{P}) ; 168.1(\mathrm{C}=\mathrm{O})$. ${ }^{31} \mathrm{P}-\mathrm{NMR}$ (DMSO): $3.5 \mathrm{ppm}$.

\subsection{Dodecyldiamino-2-tetraphosphonic Acetic Acid}

$2.00 \mathrm{~g}$ of dodecyldiamine ( $10 \mathrm{mmol}), 3.28 \mathrm{~g}$ of phosphorous acid $(40 \mathrm{mmol}), 4 \mathrm{~mL}$ of water and $3.68 \mathrm{~g}$ of glyoxylic acid monohydrate $(40 \mathrm{mmol})$ were used according to the amines' general procedure. After evaporation, the product was crystallized in isopropanol, filtered and then washed with water. White solid, isolated yield $66 \% . \mathrm{Mp}=116-117^{\circ} \mathrm{C}$. ${ }^{1} \mathrm{H}-\mathrm{NMR}: 1.21-1.32\left(\mathrm{~m}, 16 \mathrm{H}, \mathrm{CH}_{2}\right) ; 1.51\left(\mathrm{t}, \mathrm{J}=7.6 \mathrm{~Hz}, 4 \mathrm{H}, \mathrm{CH}_{2}\right) ; 2.72(\mathrm{t}, \mathrm{J}=7.6 \mathrm{~Hz}, 4 \mathrm{H}$, $\left.\mathrm{N}-\mathrm{CH}_{2}\right) ; 3.31$ (s, 4H, N-CH-P). ${ }^{13} \mathrm{C}-\mathrm{NMR}: 25.3 ; 25.6 ; 28.1\left(10 * \mathrm{CH}_{2}\right) ; 28.4 ; 28.5\left(\mathrm{CH}_{2}-\mathrm{N}\right) ; 47.6$ (P-CH-N); 169.6 (C=O). ${ }^{31} \mathrm{P}-\mathrm{NMR}: 4.9 \mathrm{ppm}$. 


\subsection{P-xylenediamino-2-tetraphosphonic Acetic Acid}

$2.72 \mathrm{~g}$ of p-xylenediamine ( $20 \mathrm{mmol}), 6.56 \mathrm{~g}$ of phosphorous acid $(80 \mathrm{mmol}), 3 \mathrm{~mL}$ of water and $7.42 \mathrm{~g}$ glyoxylic acid monohydrate $(80 \mathrm{mmol})$ were used according to the amines' general procedure with irradiation duration of $8 \mathrm{~min}$ at $200 \mathrm{~W}$. After evaporation, the product was crystallized in isopropanol, filtered and then washed with water. White solid, isolated yield $65 \% . \mathrm{Mp}=224-225^{\circ} \mathrm{C} .{ }^{1} \mathrm{H}-\mathrm{NMR}: 3.81\left(\mathrm{~s}, 4 \mathrm{H}, \mathrm{CH}_{2}-\mathrm{N}\right) ; 4.27(\mathrm{~s}, 4 \mathrm{H}, \mathrm{N}-\mathrm{CH}-\mathrm{P})$; 7.50 (m, 4H, HAr). ${ }^{13} \mathrm{C}-\mathrm{NMR}: 47.1\left(\mathrm{NCH}_{2}\right) ; 50.3$ (N-CH-P); 129.6; 130.7; 130.8; 131.8 (CAr); $169.4(\mathrm{C}=\mathrm{O}) .{ }^{31} \mathrm{P}-\mathrm{NMR}: 5.2 \mathrm{ppm}$.

\subsection{Dibutylaminophosphonic Acetic Acid}

$2.58 \mathrm{~g}$ of dibutylamine (20 mmol), $3.28 \mathrm{~g}$ of phosphorous acid $(40 \mathrm{mmol}), 4 \mathrm{~mL}$ of water and $3.68 \mathrm{~g}$ glyoxylic acid monohydrate $(40 \mathrm{mmol})$ were used according to the amines' general procedure. White solid, isolated yield $41 \% . \mathrm{Mp}=216-217{ }^{\circ} \mathrm{C}$. ${ }^{1} \mathrm{H}-\mathrm{NMR}: 0.80\left(\mathrm{t}, \mathrm{J}=6.4 \mathrm{~Hz}, 6 \mathrm{H}, \mathrm{CH}_{3}\right) ; 1.23\left(\mathrm{~m}, 4 \mathrm{H}, \mathrm{CH}_{2}\right) ; 1.56\left(\mathrm{t}, \mathrm{J}=7.2 \mathrm{~Hz}, 4 \mathrm{H}, \mathrm{CH}_{2}\right)$; $2.79\left(\mathrm{t}, \mathrm{J}=7.2 \mathrm{~Hz}, 4 \mathrm{H}, \mathrm{CH}_{2}-\mathrm{N}\right) ; 3.37(\mathrm{~s}, 1 \mathrm{H}, \mathrm{N}-\mathrm{CH}-\mathrm{P}) .{ }^{13} \mathrm{C}-\mathrm{NMR}: 13.6\left(\mathrm{CH}_{3}\right) ; 29.4\left(\mathrm{CH}_{2}\right)$; $30.9\left(\mathrm{CH}_{2}\right) ; 54.2\left(\mathrm{~N}^{\left.-\mathrm{CH}_{2}\right)}\right) ; 5.1(\mathrm{CH}-\mathrm{N}) ; 165.6(\mathrm{C}=\mathrm{O}) .{ }^{31} \mathrm{P}-\mathrm{NMR}: 3.5 \mathrm{ppm}$.

\subsection{General Procedure for Amino Acids}

One equivalent of amino acid is added to two equivalents phosphorous acid diluted in a little amount of water, and the mixture is placed in a quartz tube or in a glass vessel. Next, two equivalents of glyoxylic acid diluted in water are quickly added, and the flask is microwave irradiated or refluxed. After cooling, when the product precipitates in the tube, it is then filtered and washed with water or isopropanol.

\subsection{L-amino-3-phenylpropanoic Diphosphonic Acetic Acid}

$5.0 \mathrm{~g}$ of $L$-phenylalanine ( $30 \mathrm{mmol}), 4.96 \mathrm{~g}$ of phosphorous acid $(60 \mathrm{mmol})$ in $15 \mathrm{~mL}$ of water and $5.57 \mathrm{~g}$ of glyoxylic acid monohydrate $(60 \mathrm{mmol})$ were used according to the amino acids' general procedure during $10 \mathrm{~min}$ irradiation at $150 \mathrm{~W}$. The crystals formed were filtered and recrystallized in isopropanol. White solid, isolated yield $30 \%$. $\mathrm{Mp}=247-248{ }^{\circ} \mathrm{C} .{ }^{1} \mathrm{H}-\mathrm{NMR}: 2.85\left(\mathrm{~m}, 2 \mathrm{H}, \mathrm{CH}_{2}\right.$-Ar); $3.04(\mathrm{q}, \mathrm{J}=16.4 \mathrm{~Hz}, \mathrm{~J}=10.0 \mathrm{~Hz}, 2 \mathrm{H}$, $\mathrm{N}-\mathrm{CHP}) ; 3.28(\mathrm{t}, \mathrm{J}=7.0 \mathrm{~Hz}, 1 \mathrm{H}, \mathrm{N}-\mathrm{CH}-\mathrm{C}) ; 7.23(\mathrm{~m}, 5 \mathrm{H}, \mathrm{HAr}) .{ }^{13} \mathrm{C}-\mathrm{NMR}: 38.8\left(\mathrm{CH}_{2}\right)$; 50.6 (N-CH-C); 64.6 (P-CHN); 126.7; 128.6; 129.3; 137.9 (CAr); 178.3; 180.4 (C=O). ${ }^{31}$ P-NMR: $4.9 \mathrm{ppm} .[\alpha]_{\mathrm{D}}=-0.87^{\circ}\left(\mathrm{c}=0.92, \mathrm{H}_{2} \mathrm{O}\right)$.

\subsection{L-amino-2 Methyl-4 Pentanoic Diphosphonic Acetic Acid}

$2.62 \mathrm{~g}$ of L-leucine $(20 \mathrm{mmol})$ and $3.28 \mathrm{~g}$ of phosphorous acid $(40 \mathrm{mmol})$ in $3 \mathrm{~mL}$ water and a solution of $3.68 \mathrm{~g}$ of glyoxylic acid monohydrate $(40 \mathrm{mmol})$ in $3 \mathrm{~mL}$ water were used according to the amino acids' general procedure during 10 min irradiation at $150 \mathrm{~W}$. The crystals formed were filtered and recrystallized in isopropanol. White solid, isolated yield $18 \%$.

$2.62 \mathrm{~g}$ of $L$-leucine $(20 \mathrm{mmol})$ and $3.28 \mathrm{~g}$ of phosphorous acid $(40 \mathrm{mmol})$ in $3 \mathrm{~mL}$ water and a solution of $3.68 \mathrm{~g}$ of glyoxylic acid monohydrate $(40 \mathrm{mmol})$ in $3 \mathrm{~mL}$ water were used according to the amino acids' general procedure, and the flask was refluxed for $6 \mathrm{~h}$. After cooling, the product was crystallized in isopropanol. White solid, isolated yield $22 \% . \mathrm{Mp}=211-212{ }^{\circ} \mathrm{C} .{ }^{1} \mathrm{H}-\mathrm{NMR}: 0.90\left(\mathrm{~d}, \mathrm{~J}=5.6 \mathrm{~Hz}, 6 \mathrm{H}, \mathrm{CH}_{3}\right) ; 1.71-1.80(\mathrm{~m}, 3 \mathrm{H}, \mathrm{C}-\mathrm{CH}-\mathrm{C}$, $\left.\mathrm{CH}_{2}\right) ; 3.75(\mathrm{~m}, 1 \mathrm{H}, \mathrm{N}-\mathrm{CH}-\mathrm{C}) ; 3.81(\mathrm{~m}, 2 \mathrm{H}, \mathrm{N}-\mathrm{CH}-\mathrm{P}) .{ }^{13} \mathrm{C}-\mathrm{NMR}: 21.1 ; 21.7\left(2{ }^{*} \mathrm{CH}_{3}\right) ; 24.3$ $\left(\mathrm{CH}_{2}\right) ; 38.6(\mathrm{CH}) ; 47.0(\mathrm{~N}-\mathrm{CH}-\mathrm{C}) ; 59.9$ (P-CH-N); 169.8; 172.9 (C=O). ${ }^{31} \mathrm{P}-\mathrm{NMR}: 5.9$ ppm. $[\alpha]_{\mathrm{D}}=+8.5^{\circ}\left(\mathrm{c}=1, \mathrm{H}_{2} \mathrm{O}\right)$.

\subsection{L-amino-2 p-Hydroxyphenyl-3 Propanoic Diphosphonic Acetic Acid}

$1.81 \mathrm{~g}$ of L-tyrosine $(10 \mathrm{mmol})$ and $1.64 \mathrm{~g}$ phosphorous acid $(20 \mathrm{mmol})$ in $5 \mathrm{~mL}$ of water and a solution of $3.68 \mathrm{~g}$ glyoxylic acid monohydrate $(40 \mathrm{mmol})$ in $5 \mathrm{~mL}$ water were used according to the amino acids' general procedure during 15 min irradiation at $160 \mathrm{~W}$. White solid, isolated yield $31 \% . \mathrm{Mp}=236-237^{\circ} \mathrm{C} .{ }^{1} \mathrm{H}-\mathrm{NMR}: 3.00-3.17\left(\mathrm{~m}, 2 \mathrm{H}, \mathrm{CH}_{2}\right)$; 
3.62-3.77 (m, 2H, CH); 4.03 (m, 1H, N-CH-P); 6.82 (d, J = 8.4 Hz, 2H, HAr); 7.13 (t, J = 6.8 Hz, 2H, HAr). ${ }^{13} \mathrm{C}-\mathrm{NMR}: 34.6\left(\mathrm{CH}_{2}\right) ; 47.3$ (N-CH-C); 62.5 (P-CH-N); 115.8; 125.9; 130.7 (CAr); 155.0 C-OH; 169.8; $171.8(\mathrm{C}=\mathrm{O}) .{ }^{31} \mathrm{P}-\mathrm{NMR}: 4.7 \mathrm{ppm}$. [ $\left.\alpha\right] \mathrm{D}=+0.6^{\circ}\left(\mathrm{c}=1, \mathrm{H}_{2} \mathrm{O}\right)$.

\subsection{N-phosphonic Acetic Acid of Glutathione}

$1.53 \mathrm{~g}$ of $L$-glutathione $(5 \mathrm{mmol})$ and $0.82 \mathrm{~g}$ phosphorous acid $(10 \mathrm{mmol})$ in $5 \mathrm{~mL}$ of water and a solution of $0.92 \mathrm{~g}$ of glyoxylic acid monohydrate $(10 \mathrm{mmol})$ were used according to the amino acids' general procedure, and the flask was refluxed under argon for $8 \mathrm{~h}$. Water was then evaporated, and oil was obtained, and that was then crystallized in a mixture of water/isopropanol. The product was then filtered and recrystallized in isopropanol. White solid, isolated yield 30\%. $\mathrm{Mp}=190{ }^{\circ} \mathrm{C}(\mathrm{dec}) .{ }^{1} \mathrm{H}-\mathrm{NMR}\left(\mathrm{D}_{2} \mathrm{O}\right): 2.10-2.12$ $\left(\mathrm{m}, 2 \mathrm{H}, \mathrm{CH}_{2}\right) ; 2.51\left(\mathrm{t}, \mathrm{J}=6.4 \mathrm{~Hz}, 2 \mathrm{H}, \mathrm{CH}_{2}-\mathrm{CO}\right) ; 3.40-3.51\left(\mathrm{~m}, 2 \mathrm{H}, \mathrm{CH}_{2}-\mathrm{S}\right) ; 3.70$ (s, 2H, P-CH$\mathrm{N}) ; 3.80\left(\mathrm{~s}, 2 \mathrm{H}, \mathrm{CH}_{2}-\mathrm{COOH}\right) ; 3.91(\mathrm{t}, \mathrm{J}=6.4 \mathrm{~Hz}, 1 \mathrm{H}, \mathrm{C}-\mathrm{CH}-\mathrm{N}) .{ }^{13} \mathrm{C}-\mathrm{NMR}\left(\mathrm{D}_{2} \mathrm{O}\right): 25.0\left(\mathrm{CH}_{2}\right)$; $29.5\left(\mathrm{~S}-\mathrm{CH}_{2}\right) ; 40.3\left(\mathrm{CH}_{2}\right) ; 47.7\left(\mathrm{~N}-\mathrm{CH}_{2}\right) ; 52.6 ; 63.3(2 * \mathrm{CH}-\mathrm{N}) ; 69.0 ; 70.4(2 * \mathrm{~N}-\mathrm{CHP}) ; 169.6$; $170.4(\mathrm{CO}) ; 172.3 ; 173.6 ; 174.1 ; 176.4(\mathrm{COOH}) .{ }^{31} \mathrm{P}-\mathrm{NMR}\left(\mathrm{D}_{2} \mathrm{O}\right): 4.8 \mathrm{ppm}$.

\subsection{Ethyleneimine N-phosphonoacetic Acid Polymer}

$8.61 \mathrm{~g}$ of ethyleneimine polymer (50\% in water, $\mathrm{Mr} 750.000,100 \mathrm{mmol}), 6.02 \mathrm{~g}$ of phosphorous acid (73 mmol), $15 \mathrm{~mL}$ of water and $6.46 \mathrm{~g}$ of glyoxylic acid monohydrate (71 mmol) were used according to the general procedure. The mixture was irradiated for $8 \mathrm{~min}$ at $210 \mathrm{~W}$. The solution was dialyzed with water. After evaporation, a polymer was obtained as a glassy solid. Yield 45\%. ${ }^{1} \mathrm{H}-\mathrm{NMR}\left(\mathrm{D}_{2} \mathrm{O}\right): 2.67 ; 2.80(\mathrm{~m}, \mathrm{~N}-\mathrm{CH}) ; 3.08 ; 3.39$; $3.54\left(\mathrm{~m}, \mathrm{~N}-\mathrm{CH}_{2}\right) .{ }^{13} \mathrm{C}-\mathrm{NMR}\left(\mathrm{D}_{2} \mathrm{O}\right): 43.5-46.2$ and $47.9-50.7\left(\mathrm{~N}-\mathrm{CH}_{2}\right) ; 55.8-56.9(\mathrm{P}-\mathrm{CH}-\mathrm{N})$; $160.6(\mathrm{C}=\mathrm{O}) .{ }^{31} \mathrm{P}-\mathrm{NMR}: 4.4 \mathrm{ppm}$. IR $\left(\mathrm{cm}^{-1}\right)$ : $3336\left(v \mathrm{OH}^{\mathrm{L}}\right) ; 1637(v \mathrm{C}=\mathrm{O}) ; 1160(v \mathrm{P}=\mathrm{O})$; $1067(v \mathrm{P}=\mathrm{O})$.

\subsection{4. (3.S)-2,3,4,9-Tetrahydro-1h-pyrido[3,4-b]indole-1,3-dicarboxylic Acid}

$2.04 \mathrm{~g}$ of $L$-tryptophan $(10 \mathrm{mmol}), 20 \mathrm{~mL}$ of water, $0.82 \mathrm{~g}$ of phosphorous acid $(10 \mathrm{mmol})$ and $0.92 \mathrm{~g}$ of glyoxylic acid monohydrate $(10 \mathrm{mmol})$ were used according to the general procedure at $150 \mathrm{~W}$ for $5 \mathrm{~min}$. The product that precipitated directly in the flask was then filtered and washed with water. Yield 93\%. $\mathrm{Mp}=270-271{ }^{\circ} \mathrm{C}$ [22]. ${ }^{1} \mathrm{H}-\mathrm{NMR}$ $\left(\mathrm{CDCl}_{3}\right)$ : 2.63-2.71 (m, 1H, $\left.\mathrm{CH}_{2}\right) ; 3.04-3.10\left(\mathrm{~m}, 1 \mathrm{H}, \mathrm{CH}_{2}\right) ; 3.51-3.55(\mathrm{~m}, 1 \mathrm{H}, \mathrm{N}-\mathrm{CH}) ; 4.63$ (s, $1 \mathrm{H}, \mathrm{N}-\mathrm{CH}) ; 7.05$ (t, J = 7.0 Hz, 1H, HAr); 7.13 (t, J = 7.0 Hz, 1H, HAr); 7.38 (d, J = 8.1 Hz, 1H, HAr); 7.49 (d, J = 7.9 Hz, 1H, HAr). ${ }^{13} \mathrm{C}-\mathrm{NMR}\left(\mathrm{CDCl}_{3}\right): 25.3\left(\mathrm{CH}_{2}\right) ; 57.6 ; 59.5(2 * \mathrm{~N}-\mathrm{CH})$; $110.0 ; 114.9 ; 120.5 ; 121.8 ; 124.4 ; 128.9 ; 136.0 ; 138.5$ (CHAr); 177.5 and $181.7(\mathrm{C}=\mathrm{O})$.

\section{Results and Discussion}

We describe herein for the first time the formation of aminophosphonoacetic acids through the reaction of glyoxylic acid with a mixture of amine and phosphorous acid. The Kabachnik-Fields reaction of phosphines was reported by J. Heinicke et al. [27,28] but the Moedritzer-Irani reaction with glyoxylic acid was not reported.

The preliminary reactions showed that, in the case of primary amines, in the presence of glyoxylic acid and phosphorous acid in stoichiometric amounts, a mixture of mono and bis(phosphonoacetic) acids along with the starting amine was obtained according to

${ }^{31} \mathrm{P}$ NMR. Indeed, these two compounds displayed typical phosphorus chemical shifts: monophosphonoacetic acid ( $\left.{ }^{31} \mathrm{P}-\mathrm{NMR}\left(\mathrm{D}_{2} \mathrm{O}\right): 1.3-1.5 \mathrm{ppm}\right)$ and bis-(phosphonoacetic acid) ( $\left.{ }^{31} \mathrm{P}-\mathrm{NMR}\left(\mathrm{D}_{2} \mathrm{O}\right): 4.8-4.9 \mathrm{ppm}\right)$. Subsequently, we performed the reaction with two equivalents of phosphorus and glyoxylic acids in order to obtain only pure bis(phosphonoacetic) acid (Scheme 3). 


$$
\mathrm{R}-\mathrm{NH}_{2}+\mathrm{HOOC}-\mathrm{CHO}+\mathrm{H}_{3} \mathrm{PO}_{3} \longrightarrow\left\{\begin{array}{l}
\mathrm{x} \text { R-NH-CH }(\mathrm{COOH}) \mathrm{PO}(\mathrm{OH})_{2} \\
+\mathrm{xR}-\mathrm{NH}_{2} \\
+(1-\mathrm{x}) \mathrm{R}-\mathrm{N}\left[\mathrm{CH}(\mathrm{COOH}) \mathrm{PO}(\mathrm{OH})_{2}\right]_{2}
\end{array}\right.
$$

Scheme 3. Influence of the relative amounts of reagents in the synthesis of phosphonoacetic acids.

The MCR of glyoxylic acid, phosphorous acid and amine takes place in water by simple heating or better, by microwave activation. It is noteworthy that glyoxylic acid is a sufficiently strong acid, so it is not necessary, contrary to the protocol of MoedritzerIrani [13], to add hydrochloric acid for catalyzing the reaction. According to ${ }^{31} \mathrm{P}$ NMR, the reaction is practically total with primary amines; however, with the products obtained being very water soluble, their recovery could be difficult because of their poor crystallization in aqueous solvents. Our attempts to evaporate mother liquors led to a sticky, viscous liquid containing the product ( ${ }^{31} \mathrm{P}$ NMR) with impurities and did not permit improving the isolated yields of products. With the same amine, in comparison with the methylenephosphonic acid prepared by the Moedritzer-Irani reaction, the corresponding phosphonoacetic acid was much more water soluble.

Concerning primary amines, the synthesis of crystallized 2-amino-bis(2-phosphonoacetic) acids was achieved successfully from fatty amines of $C_{8}$ to $C_{12}$.

With shorter chain amines, the products were formed, but they were too soluble and too hygroscopic to induce their crystallization. With hindered primary amines like 1 -adamantanamine, $t$-butylamine or $t$-octylamine, no reaction at all was observed. Secondary amines like dibutylamine reacted efficiently, but no reaction occurred with hindered dicyclohexylamine under the Moedritzer-Irani conditions described herein.

All phosphonoacetic acids obtained were reported in the Table 1.

Table 1. Phosphonoacetic acids obtained from various primary and secondary amines and diamines.

\begin{tabular}{|c|c|c|c|}
\hline Amine & Product & Yield $^{a}$ & Yield $^{b}$ \\
\hline 1-butylamine & $\mathrm{CH}_{3}\left(\mathrm{CH}_{2}\right)_{3}-\mathrm{N}\left[\mathrm{CH}(\mathrm{COOH})\left(\mathrm{PO}(\mathrm{OH})_{2}\right)\right]_{2}$ & 92 & - \\
\hline 1-hexylamine & $\mathrm{CH}_{3}\left(\mathrm{CH}_{2}\right)_{5}-\mathrm{N}\left[\mathrm{CH}(\mathrm{COOH})\left(\mathrm{PO}(\mathrm{OH})_{2}\right)\right]_{2}$ & 92 & - \\
\hline 1-octylamine & $\mathrm{CH}_{3}\left(\mathrm{CH}_{2}\right)_{7}-\mathrm{N}\left[\mathrm{CH}(\mathrm{COOH})\left(\mathrm{PO}(\mathrm{OH})_{2}\right)\right]_{2}$ & 90 & 39 \\
\hline 1-decylamine & $\mathrm{CH}_{3}\left(\mathrm{CH}_{2}\right)_{9}-\mathrm{N}\left[\mathrm{CH}(\mathrm{COOH})\left(\mathrm{PO}(\mathrm{OH})_{2}\right)\right]_{2}$ & 90 & 40 \\
\hline 1-dodecylamine & $\mathrm{CH}_{3}\left(\mathrm{CH}_{2}\right)_{11}-\mathrm{N}\left[\mathrm{CH}(\mathrm{COOH})\left(\mathrm{PO}(\mathrm{OH})_{2}\right)\right]_{2}$ & - & 50 \\
\hline dibutylamine & {$\left[\mathrm{CH}_{3}\left(\mathrm{CH}_{2}\right)_{2}\right]_{2} \mathrm{NCH}(\mathrm{COOH})\left(\mathrm{PO}(\mathrm{OH})_{2}\right)$} & - & 41 \\
\hline dicyclohexylamine & $\left(\mathrm{C}_{6} \mathrm{H}_{11}\right)_{2} \mathrm{NCH}(\mathrm{COOH})\left(\mathrm{PO}(\mathrm{OH})_{2}\right)$ & 0 & - \\
\hline$t$-butylamine & $\left(\mathrm{CH}_{3}\right)_{3} \mathrm{C}-\mathrm{N}\left[\mathrm{CH}(\mathrm{COOH})\left(\mathrm{PO}(\mathrm{OH})_{2}\right]_{2}\right.$ & 0 & - \\
\hline t-octylamine & $\mathrm{C}_{4} \mathrm{H}_{9} \mathrm{CH}_{2}\left(\mathrm{CH}_{3}\right)_{2} \mathrm{C} \mathrm{N}\left[\mathrm{CH}(\mathrm{COOH})\left[\mathrm{PO}(\mathrm{OH})_{2}\right]_{2}\right.$ & 0 & - \\
\hline 1-adamantanamine & $\mathrm{C}_{10} \mathrm{H}_{17} \mathrm{~N}\left[\mathrm{CH}(\mathrm{COOH})\left(\mathrm{PO}(\mathrm{OH})_{2}\right]_{2}\right.$ & 0 & - \\
\hline 1,2-diaminoethane & $\begin{array}{c}{\left[(\mathrm{HOOC})\left[(\mathrm{HO})_{2} \mathrm{PO}_{2} \mathrm{CH}\right]_{2}\right.} \\
\mathrm{N}\left(\mathrm{CH}_{2}\right)_{2} \mathrm{~N}\left[\mathrm{CH}(\mathrm{COOH})\left[\mathrm{PO}(\mathrm{OH})_{2}\right]\right]_{2}\end{array}$ & 82 & - \\
\hline 1,12-diaminododecane & $\begin{array}{c}{\left[(\mathrm{HOOC})\left[(\mathrm{HO})_{2} \mathrm{PO}\right]_{2} \mathrm{CH}\right]_{2}} \\
\mathrm{~N}\left(\mathrm{CH}_{2}\right)_{12} \mathrm{~N}\left[\mathrm{CH}(\mathrm{COOH})\left[\mathrm{PO}(\mathrm{OH})_{2}\right]\right]_{2}\end{array}$ & - & 66 \\
\hline$p$-xylenediamine & $\begin{array}{c}{\left[(\mathrm{HOOC})\left[(\mathrm{HO})_{2} \mathrm{PO}\right]_{2}\right.} \\
\mathrm{CH}]_{2} \mathrm{NCH}_{2} \mathrm{C}_{6} \mathrm{H}_{4} \mathrm{CH}_{2} \mathrm{~N}\left[\mathrm{CH}(\mathrm{COOH})\left[\left(\mathrm{PO}(\mathrm{OH})_{2}\right]\right]_{2}\right.\end{array}$ & - & 65 \\
\hline
\end{tabular}

$\left({ }^{a}\right)$ Yield (\%) estimated from reacting solution by ${ }^{31} \mathrm{P}-\mathrm{NMR}$. $\left({ }^{\mathrm{b}}\right)$ Yield (\%) of isolated product by crystallization.

Moreover, this approach has been used to provide rapid and easy access to polyamine containing both phosphonic and carboxylic acid groups. In the past, we have already shown that hyperbranched PEI could be phosphonated by the reaction of Moedritzer-Irani into an exchanging resin of cations [29] with a very great capacity for absorption of heavy metal cations such Pb, Bi or U. The hyperbranched PEI, in the presence of glyoxylic acid, 
is transformed into an amino (2-phosphonoacetic) polymer and therefore constitutes also a very good chelating resin of the cations [30] according the Scheme 4.

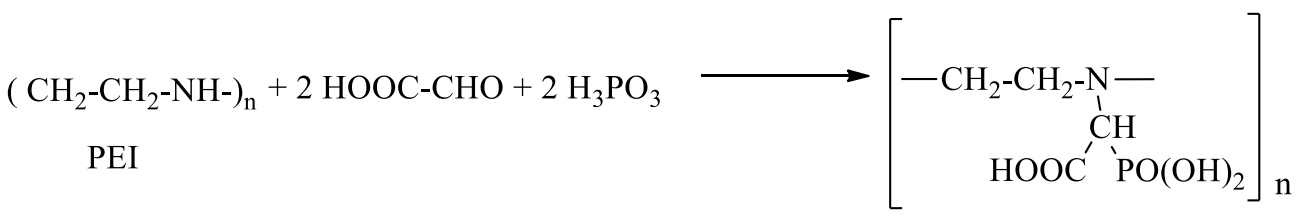

Scheme 4. Modification of hyperbranched polyethylenimine PEI into cation-chelating resin.

Finally, we investigated the transformation of some natural amino acids and one peptide (glutathione) under the same operatory conditions (see Table 2). In the case of $L$-phenylalanine, $L$-tyrosine, $L$-leucine and $L$-glutathione, the reaction was achieved, leading to the corresponding amino-bis(2-phosphonoacetic) acids. However, the yields of crystallized products were poor due to the very great water solubility of the products.

Table 2. Transformation of amino acids and peptide into phosphonoacetic acid derivatives.

Starting Reactant

In the specific case of $L$-leucine, a better yield was surprisingly obtained under refluxed conditions than microwave irradiation. Similarly, the glutathione derivative was prepared under refluxed conditions under an argon atmosphere because the Synthewave microwave oven could not work under the rigorous exclusion of oxygen required by reduced glutathione. On the other hand, it was not possible to specify the chirality of the two new stereocenters created. In the case of tripeptide glutathione, the amino group was transformed, and no reaction seems takes place with amide group. 
Surprisingly, L-tryptophan did not give the expected phosphonoacetic acid compound. Instead, a very smooth Pictet-Spengler reaction [31] occurred in the presence of phosphorous acid, affording 2,3,4,9-tetrahydro-1H-pyrido[3,4-b]indole-1,3-dicarboxylic acid (92\%). This reaction was already reported in the literature [32] with sulfuric acid as a catalyst, but phosphorous acid seemed to be the best catalyst, with greater efficiency.

We propose a probable mechanism for this reaction (see Scheme 5): in the first step, glyoxylic acid, which is a relatively strong acid $(\mathrm{pKa}=3.3)$, is transformed into an iminium in the presence of an amine; this reaction is Bronsted acid-catalyzed reaction. Then, the reaction of the conjugate base of phosphorous acid $\left(\mathrm{pKa}_{1}=6.7\right)$ with the iminium leads to the amino phosphonoacetic acid. The process takes place twice with a primary amine, affording the expecting amino bis(2-phosphonoacetic) acids.

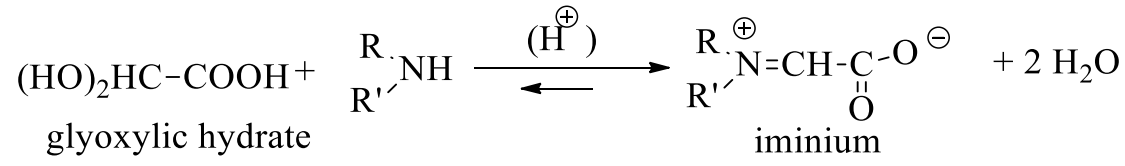

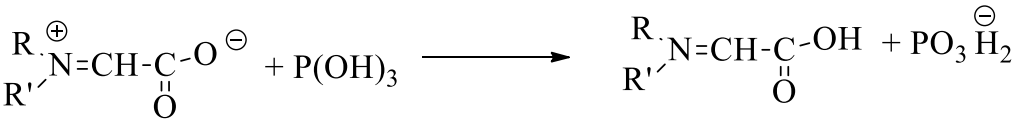

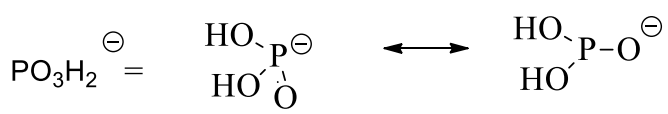

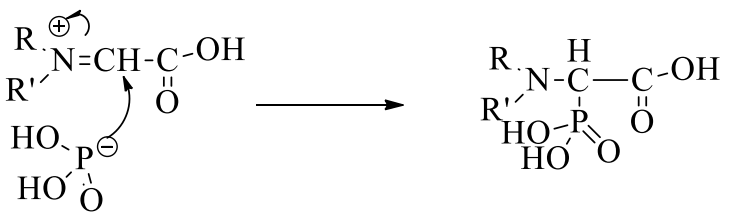

Scheme 5. Plausible mechanism for the formation of 2-amino bis(2-phosphonoacetic) acids from secondary amine. The first step consists of the formation of iminium intermediate, followed by the reaction of this iminium with phosphorous acid furnishing the aminophosphonoacetic acid.

\section{Conclusions}

The synthesis of 2-aminobis(2-phosphonoacetic) acids from amines, polyamines or amino acids by MCR under microwave irradiation is simple and fast. Moreover, the chemical conditions are environmentally friendly, as the reaction coupled to microwave irradiation is carried out in water and often, no organic solvent is used for separation and purification steps. It allows for preparing interesting, useful aminophosphonoacetic acids exhibiting versatile applications such as biologically active molecules, coordinating agents of metals or precursors of materials (organic or MOF).

Author Contributions: Conceptualization, D.V.; Investigation, B.M. and N.B.; Writing-Original draft, D.V.; Writing-Review and editing, N.B. All authors have read and agreed to the published version of the manuscript.

Funding: This research received no external funding.

Institutional Review Board Statement: Not Applicable.

Informed Consent Statement: Not Applicable.

Data Availability Statement: Not Applicable.

Acknowledgments: We gratefully acknowledge the CNRS (Centre National de la Recherche Scientifique) and the "Région Basse-Normandie" for their financial support.

Conflicts of Interest: The authors declare no conflict of interest. 


\section{References}

1. Didi, M.A.; Villemin, D. Phosphonic and Aminophosphonic acids. Synthesis and Applications, Editions Universitaires Européennes; OmniScriptum Publising: Saarbrücken, Germany, 2018; ISBN 978-620-2-27586-6.

2. Troev, K.D. Chemistry and Application of H-Phosphonates; Elsevier: Amsterdam, The Netherlands, 2006 ; ISBN 9780444527370.

3. Kukhar, V.P.; Hudson, H.R. Aminophosphonic and Aminophosphinic Acids: Chemistry and Biological Activity; John Wiley: Chichester, UK, 2000; ISBN 0-471-89149-1.

4. Kafarski, P. Phosphonopeptides containing free phosphonic groups: Recent advances. RSC Adv. 2020, 10, 25898-25910. [CrossRef]

5. Grembecka, J.; Mucha, A.; Cierpicki, T.; Kafarski, P. The most potent organophosphorus inhibitors of leucine aminopeptidase. Structure-based design, chemistry, and activity. J. Med Chem. 2003, 46, 2641-2655. [CrossRef]

6. Hiratake, J.; Oda, J. Aminophosphonic and aminoboronic acids as key elements of a transition state analogue inhibitor of enzymes. Biosci. Biotechnol. Biochem. 1997, 61, 211-218. [CrossRef]

7. Cameron, D.G.; Hudson, H.R.; Pianka, M. Aminoalkynephosphonic acids in agricultural fungicides: A new development in crop protection chemicals. Phosphorus Sulfur Silicon Relat. Elem. 1990, 51, 391. [CrossRef]

8. Hsieh-Wilson, L.C.; Schultz, P.G.; Stevens, R.C. Insights into antibody catalysis: Structure of an oxygenation catalyst at 1.9angstrom resolution. Proc. Natl. Acad. Sci. USA 1996, 93, 5363-5367. [CrossRef] [PubMed]

9. Kabachnik, M.I.; Medved, T.Y.; Dyatlova, N.M.; Arkhipova, O.G.; Rudomino, M.V. Organophosphorus complexones. Russ. Chem. Rev. 1968, 37, 503-518. [CrossRef]

10. Kabachnik, M.I.; Medved, T.Y.; Dyatlova, N.M.; Rudomino, M.V. Organophosphorus complexones. Russ. Chem. Rev. 1974, 43, 733-744. [CrossRef]

11. Amar, H.; Benzakour, J.; Derja, A.; Villemin, D.; Moreau, B. A corrosion inhibition study of iron by phosphonic acids in sodium chloride solution. J. Electroanal. Chim. 2003, 558, 131-139. [CrossRef]

12. Amar, H.; Benzakour, J.; Derja, A.; Villemin, D.; Moreau, B. Investigation of the inhibitive effect of phosphonic acids on corrosion of iron in sodium chloride 3\% media. Corros. Eng. Sci. Technol. 2006, 41, 291-296. [CrossRef]

13. Didi, M.A.; Kaid, M.; Baghdad, M.; Villemin, D. Aminododecyldiphosphonic acid for solvent extraction of bismuth ions. Int. J. Nonferrous Metal. 2012, 1, 59-64. [CrossRef]

14. Mutin, P.H.; Guerrero, G.; Vioux, A. Organic-inorganic hybrid materials based on organophosphorus coupling molecules: From metal phosphonates to surface modification of oxides. Comptes Rendus Chim. 2003, 6, 1153-1164. [CrossRef]

15. Monteil, C.; Bar, N.; Retoux, R.; Henry, J.; Bernay, B.; Villemin, D. Partially phosphonated polyethylenimine-coated nanoparticles as convenient support for enzyme immobilization in bioprocessing. Sens. Actuators B 2014, 192, 269-274. [CrossRef]

16. Rosario, M.P.; Colodrero, R.M.P.; Olivera-Pastor, P.; Losilla, E.R.; Hernández-Alonso, D.; Aranda, M.A.G.; Leon-Reina, L.; Rius, J.; Demadis, K.D.; Moreau, B.; et al. High proton conductivity in a flexible, cross-linked, ultramicroporous magnesium tetraphosphonate hybrid framework. Inorg. Chem. 2012, 51, 7689-7698. [CrossRef]

17. Turner, A.; Jaffrés, P.-A.; MacLean, E.J.; Villemin, D.; McKee, V.; Hix, G.B. Hydrothermal synthesis and crystal structure of two Co phosphonates containing trifunctional phosphonate anions: $\mathrm{Co}_{3}\left(\mathrm{O}_{3} \mathrm{PCH}_{2} \mathrm{NH}_{2} \mathrm{CH}_{2} \mathrm{PO}_{3}\right)_{2}$ and $\mathrm{Co}_{3}\left(\mathrm{O}_{3} \mathrm{PCH}_{2}-\mathrm{NC}_{4} \mathrm{H}_{7}-\mathrm{CO}_{2}\right)_{2} .5 \mathrm{H}_{2} \mathrm{O}$. J. Chem. Soc. Dalton Trans. 2003, 1314-1319. [CrossRef]

18. Moedritzer, K.; Irani, R. The direct synthesis of $\alpha$-aminomethylphosphonic acids. Mannich-type reactions with orthophosphorous acid. J. Org. Chem. 1966, 31, 1603-1607. [CrossRef]

19. Siméon, F.; Saint-Clair, J.F.; Villemin, D. Alkylmethyleneamino phosphonic acids synthesis under microwave irradiation. In Proceedings of the First International Conference on Microwave Chemistry, Prague, Czeck Republic, 7-11 September 1998; p. 186.

20. Villemin, D.; Moreau, B.; Didi, M.A.; Kaid, M.; Jaffrès, P.-A. Synthesis in Water under Focussed Microwave Irradiation: A Rapid and Convenient Synthesis of Polyaminopolymethylene Phosphonic Acids. In Proceedings of the 12th International Electronic Conference on Synthetic Organic Chemistry (ECSOC-12), sciforum.net, MDPI. 1-30 November 2008; [E0002]. Available online: https:/ / sciforum.net/paper/view/ conference/1252 (accessed on 1 May 2021).

21. Villemin, D.; Moreau, B.; Elbilali, A.; Didi, M.A.; Kaid, M.; Jaffrès, P.-A. Green synthesis of poly(aminomethylene phosphonic) acids. Phosphorus Sulfur Silicon Relat. Elem. 2010, 185, 1-9. [CrossRef]

22. Cherkasov, R.A.; Galkin, V.I. The Kabachnik-Fields reaction: Synthetic potential and the problem of the mechanism. Russ. Chem. Rev. 1998, 67, 857-882. [CrossRef]

23. Fields, E.K. The synthesis of esters of substituted aminophosphonic acids. J. Am. Chem. Soc. 1952, 74, 1528-1531. [CrossRef]

24. Zefirov, N.S.; Matveeva, E.A. Catalytic Kabachnik-Fields reaction: New horizons for old reaction. Arkivoc 2008, 1, 1-17. [CrossRef]

25. Villemin, D.; Didi, M.A. Aminomethylenephosphonic Acids Syntheses and Applications (A Review). Orient. J. Chem. 2015, 31, 1-12. Available online: http:/ / www.orientjchem.org/?p=10779 (accessed on 1 May 2021). [CrossRef]

26. Justyna, K.; Małolepsza, J.; Kusy, D.; Maniukiewicz, W.; Błażewska, K.M. The McKenna reaction-Avoiding side reactions in phosphonate deprotection. Beilstein J. Org. Chem. 2020, 16, 1436-1446. [CrossRef]

27. Heinicke, J.; Lach, J.; Peulecke, N.; Jones, P.G.; Dix, I. Phosphinoglycines and Phosphinoglycolates. Phosphorus Sulfur Silicon Relat. Elem. 2008, 183, 783-786. [CrossRef]

28. Heinicke, J.; Lach, J.; Basvani, K.R.; Peulecke, N.; Jones, P.G.; Köckerling, M. Phosphino amino acids: Synthesis, structure and reactivity. Phosphorus Sulfur Silicon Relat. Elem. 2011, 186, 666-677. [CrossRef]

29. Villemin, D.; Monteil, C.; Bar, N.; Didi, M.A. Phosphonated polyethyleneimines (PEIP) as multi-use polymers. Phosphorus Sulfur Silicon Relat. Elem. 2015, 190, 879-890. [CrossRef] 
30. Didi, M.A.; Miraoui, A.; Villemin, D. Neodymium (III) removal by functionalized magnetic nanoparticles. J. Rad. Nucl. Chem. 2016, 307, 963-971. [CrossRef]

31. Pictet, A.; Spengler, T. Über die Bildung von Isochinolin-derivaten durch Einwirkung von Methylal auf Phenyl-äthylamin, Phenyl-alanin und Tyrosin. Ber. Dtsch. Chem. Ges. 1911, 44, 2030-2036. [CrossRef]

32. Bobbitt, J.M.; Willis, M.P. Electrochemistry of natural products. 7. Oxidative decarboxylation of some tetrahydro-.beta.carbolinecarboxylic acids. J. Org. Chem. 1980, 45, 1978-1984. [CrossRef] 